OPEN ACCESS

Edited by:

Xue-Zhong Yu,

Medical University of South Carolina,

United States

Reviewed by:

Xuefang Cao,

University of Maryland, Baltimore,

United States

Tomomi Toubai,

Yamagata University, Japan

${ }^{*}$ Correspondence:

Yi Zhang

yi.zhang@temple.edu

Specialty section:

This article was submitted to Alloimmunity and Transplantation,

a section of the journal

Frontiers in Immunology

Received: 06 November 2018

Accepted: 14 January 2019

Published: 01 February 2019

Citation:

Yu H, Tian Y, Wang Y, Mineishi S and

Zhang Y (2019) Dendritic Cell

Regulation of Graft-vs.-Host Disease: Immunostimulation and Tolerance.

Front. Immunol. 10:93.

doi: 10.3389/fimmu.2019.00093

\section{Dendritic Cell Regulation of Graft-vs.-Host Disease: Immunostimulation and Tolerance}

\author{
Hongshuang Yu ${ }^{1}$, Yuanyuan Tian ${ }^{1}$, Ying Wang ${ }^{1}$, Shin Mineishi ${ }^{2}$ and Yi Zhang ${ }^{1,3 *}$ \\ ${ }^{1}$ Fels Institute for Cancer Research and Molecular Biology, Temple University, Philadelphia, PA, United States, ${ }^{2}$ Department \\ of Medicine, Pennsylvania State University, Hershey, PA, United States, ${ }^{3}$ Department of Microbiology \& Immunology, Temple \\ University, Philadelphia, PA, United States
}

Graft-vs.-host disease (GVHD) remains a significant cause of morbidity and mortality after allogeneic hematopoietic stem cell transplantation (allo-HSCT). Significant progresses have been made in defining the dichotomous role of dendritic cells (DCs) in the development of GVHD. Host-derived DCs are important to elicit allogeneic T cell responses, whereas certain donor-types of DCs derived from newly engrafted hematopoietic stem/progenitor cells (HSPCs) can amply this graft-vs.-host reaction. In contrast, some DCs also play non-redundant roles in mediating immune tolerance. They induce apoptotic deletion of host-reactive donor $T$ cells while promoting expansion and function of regulatory T cells (Treg). Unfortunately, this tolerogenic effect of DCs is impaired during GVHD. Severe GVHD in patients subject to allo-HSCT is associated with significantly decreased number of circulating peripheral blood DCs during engraftment. Existing studies reveal that GVHD causes delayed reconstitution of donor DCs from engrafted HSPCs, impairs the antigen presentation function of newly generated DCs and reduces the capacity of DCs to regulate Treg. The present review will discuss the importance of DCs in alloimmunity and the mechanism underlying DC reconstitution after allo-HSCT.

Keywords: graft-vs.-host, disease, dendritic cells, transcription factors, alloreactive T cells, immunostimulation, immune tolerance

\section{INTRODUCTION}

Allogenic hematopoietic stem cell transplantation (allo-HSCT) is a potentially curative therapy for many hematological malignancies, such as leukemia, lymphoma, and multiple myeloma $(1,2)$. This beneficial effect is largely derived from infused donor immune cells that can eliminate malignant cells, a process known as graft-vs.-leukemia (GVL) response (3-5). However, the success of the procedure is limited by the life-threatening complication graft-vs.-host disease (GVHD), in which the gastrointestinal (GI) tract, skin and liver are preferentially damaged (2, 6-9).

GVHD is mediated by infused donor T cells that recognize and react to histocompatibility differences between the host and donor (9-12). Host-derived antigen-presenting cells (APCs) can directly present antigens to prime allogenic donor T cells, whereas donor-derived APCs can present host antigens to donor $\mathrm{T}$ cells via indirect antigen presentation $(10,12,13)$. Initial studies demonstrate that host APCs are critical for donor $\mathrm{CD}^{+}{ }^{+} \mathrm{T}$ cell-mediated GVHD. Subsequent studies indicate that either host or donor APCs are sufficient to induce $\mathrm{CD} 4^{+} \mathrm{T}$ cell-dependent GVHD (9-12, 14-17). Importantly, unlike T cell responses to pathogens in which hematopoietic 
APCs prime $\mathrm{T}$ cells, alloreactive $\mathrm{T}$ cell responses in the setting of allo-HSCT may be primed by both hematopoietic and nonhematopoietic APCs (9-12, 14-17).

DCs are the most potent professional APCs known to elicit primary $\mathrm{T}$ cell responses (18-20). Based on their surface phenotype, anatomical location and function, DCs at the steady state are broadly categorized into conventional DCs (cDCs) and plasmacytoid DCs (pDCs). Under inflammatory condition, both DC subsets undergo profound changes in their phenotype and functionality (21-25). For example, in response to inflammatory stimuli, DCs may be primed selectively to produce special types of cytokines (e.g., IL-12, IL-23) and Notch ligands (e.g., Delta-like 1 (DLL1) and DLL4). These DC-derived molecules are important to instruct antigen-activated $\mathrm{T}$ cells to differentiate into distinct lineages of effector $\mathrm{T}$ cells, such as T helper (TH)1, TH17 cells, and cytotoxic T cells (CTLs) (26-33).

Over the past two decades, both clinical and preclinical studies have demonstrated dichotomous roles of DCs in GVHD (9, 34, 35). While some DCs induce alloreactive $\mathrm{T}$ cell responses mediating host tissue injury, other DC subsets induce donor T cell tolerance against the host tissue. In this review, we will discuss these effects of DC-mediated immunogenicity and tolerogenicity during GVHD.

\section{INDUCTION OF GVHD}

DCs are specialized APCs that play non-redundant roles in regulating both immunity and tolerance $(9,18,36-44)$. In the setting of allo-HSCT, host-derived DCs are important for donor $\mathrm{T}$ cell-mediated GVHD in the liver, colon and skin $(9-12,16$, $17,35,45)$. De novo generated donor APCs, including DCs, are also required to induce maximal GVHD through a complex mechanism $(9-11,35)$.

\section{Host DCs and Initiation of Alloreactive T Cell Responses}

Shlomchik and colleagues demonstrate, for the first time, that host hematopoietic APCs are critical for induction of the disease, and donor APCs can mediate maximal GVHD $(10,12)$. Subsequent studies reveal that host DCs, which are activated during preparative conditioning for allo-HSCT, present host antigens to prime donor $\mathrm{CD}^{+}$and $\mathrm{CD} 8^{+} \mathrm{T}$ cells and promote their proliferation and differentiation into alloreactive effector cells $(17,46)$. Add-back of WT host-type cDCs or pDCs causes severe GVHD in mice lacking MHC class-I or MHC class-II, respectively (47), further strengthening the importance of host DCs in mediating GVHD (Table 1). However, these studies do not explain whether host DCs contribute to GVHD when all the other types of host APCs, including B cells, macrophages and non-hematopoietic APCs, are intact. For example, host B cells produced high levels of IL-10 to modulate alloreactive T cell responses in vivo (57), Recipient macrophages, which resist the conditioning regimen, persisted in patients for several weeks following allo-HSCT and limited the severity of GVHD (58). In contrast, non-hematopoietic APCs activated by irradiation induce potent allo-specific responses in peripheral tissues(14, 59).

The role of host DCs in the development of GVHD in the presence of functional macrophages and non-hematopoietic APCs has been studied by several groups. Merad et al. examined the role of host Langerhans cells (LCs), a distinct subset of DCs located in the skin (19), in cutaneous GVHD (40). Administration of donor $\mathrm{T}$ cells to bone marrow (BM)-chimeric mice with persistent host LCs, but not to mice whose LCs had been replaced, resulted in marked skin GVHD (40), suggesting that host LCs are important for mediating the disease in the skin. Intriguingly, other studies show that LCs were dispensable for the induction of skin GVHD (48). In one of those studies, donor $\mathrm{T}$ cells and $\mathrm{BM}$ cells were transferred into lethally irradiated transgenic recipient mice in which epidermal LCs expressed the Diphtheria toxin A (DTA) under the control of the human Langerin locus (48). Deficiency of LCs did not affect the development of either $\mathrm{CD}^{+}{ }^{+} \mathrm{T}$ cell- or $\mathrm{CD}^{+} \mathrm{T}$ cell-mediated GVHD (48). How to reconcile these observations remains controversial.

\section{Donor DCs Amplify GVH Reaction by Cross-Presenting Host-Type Antigen}

In the setting of allo-HSCT, de novo generated donor APCs are also found to be important for GVHD $(9-11,35)$. Studies by Markey et al. suggested that donor cDCs isolated from the spleen were the most effective population in presenting alloantigens and stimulating naïve donor $\mathrm{T}$ cell responses early after alloHSCT (49). Intriguingly, upon exposure to GVH inflammation, donor $\mathrm{CD} 103^{+} \mathrm{CD}_{11} \mathrm{~b}^{-} \mathrm{cDCs}$, which are independent of the transcription factor IRF4 for their development $(60,61)$, captured alloantigen in the colon and migrated into the mesenteric lymph node to amplify alloreactive $\mathrm{T}$ cell responses (13). This suggests that tissue resident DCs may play important roles in regulating GVH reactions, which is supported by our early studies. We found that selective depletion of both host- and donor-type APCs, including DCs, in visceral organs led to significantly reduced GVHD in the liver but not in the skin (11). These observations suggest that donor DCs possess great capacity to orchestrate the alloreactive $\mathrm{T}$ cell response both in the lymphoid organ and non-lymphoid tissues, eliciting different types of GVHD.

\section{DC-Derived IL-12 and Notch Ligands Shape Alloreactive T Cell Responses}

DCs produce multiple molecules capable of shaping allogeneic $\mathrm{T}$ cell responses (Figure 1). For example, IL-12 produced by DCs drives expansion and differentiation of antigen-activated $\mathrm{T}$ cells $(13,18,27,30,62,63)$. Donor BM cells lacking IL-12 p40 had significantly decreased capacity to promote effector differentiation and expansion in the mesenteric lymph nodes of mice receiving allogenic $\mathrm{T}$ cells. IL-12 derived from $\mathrm{CD} 103^{+} \mathrm{CD}_{11 \mathrm{~b}}{ }^{-} \mathrm{cDCs}$ promoted IFN $-\gamma$ production in hostreactive $\mathrm{T}$ cells (13). Notch signaling pathway is demonstrated as an important regulator of alloreactive $\mathrm{T}$ cell responses. Using a genetic approach, we reported that inhibition of pan-Notch 


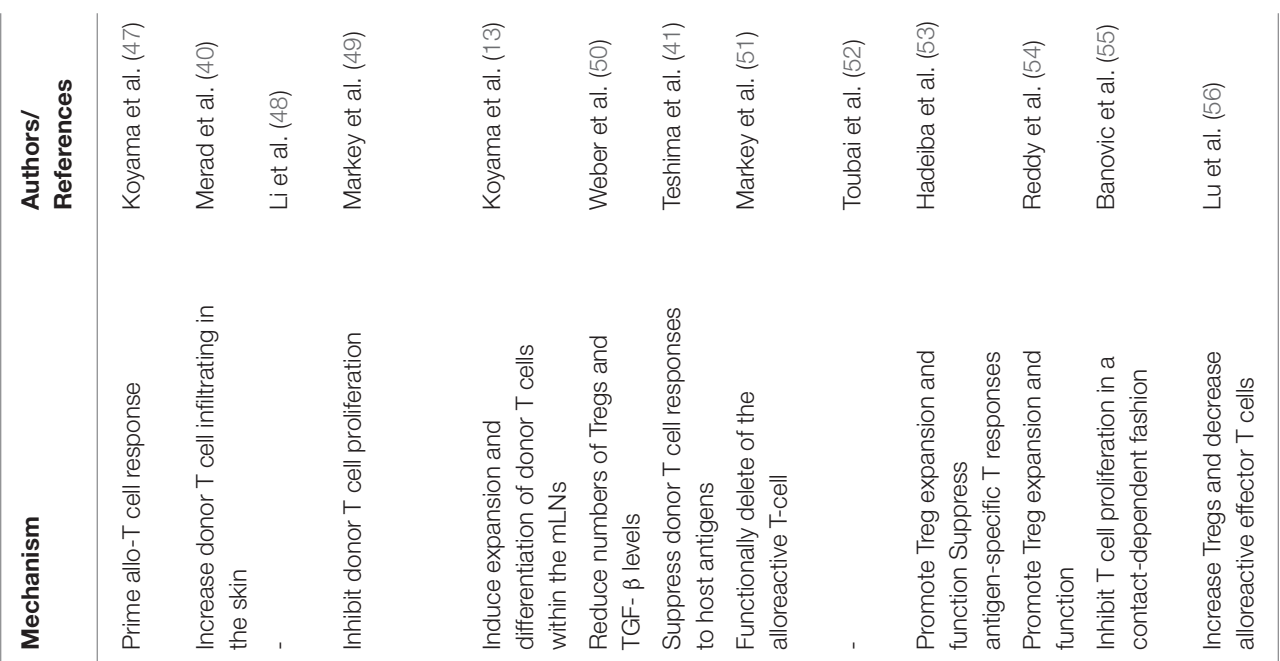

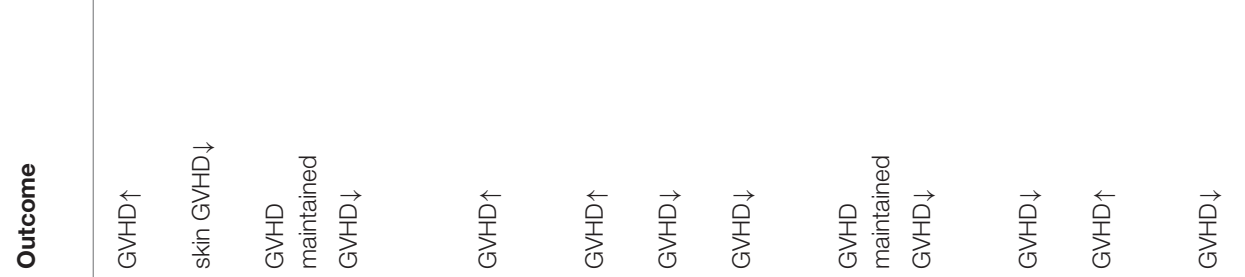

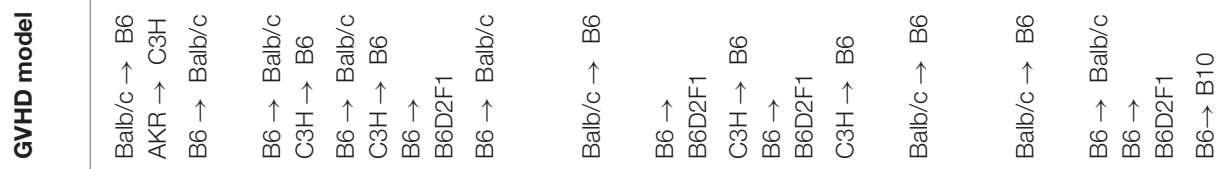

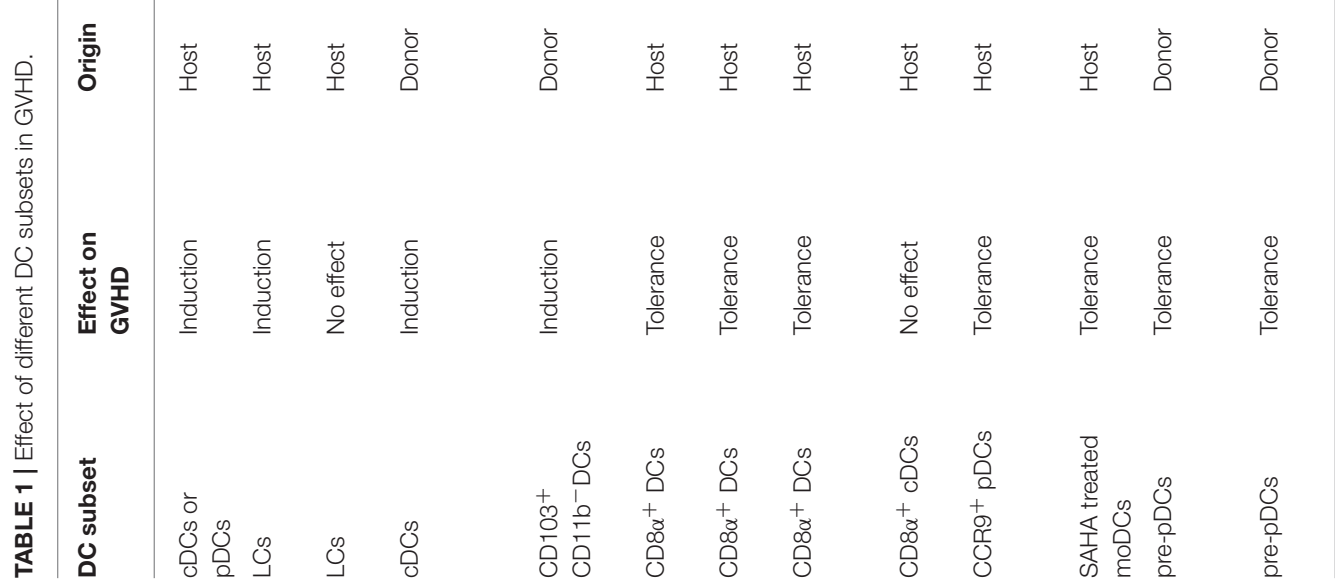




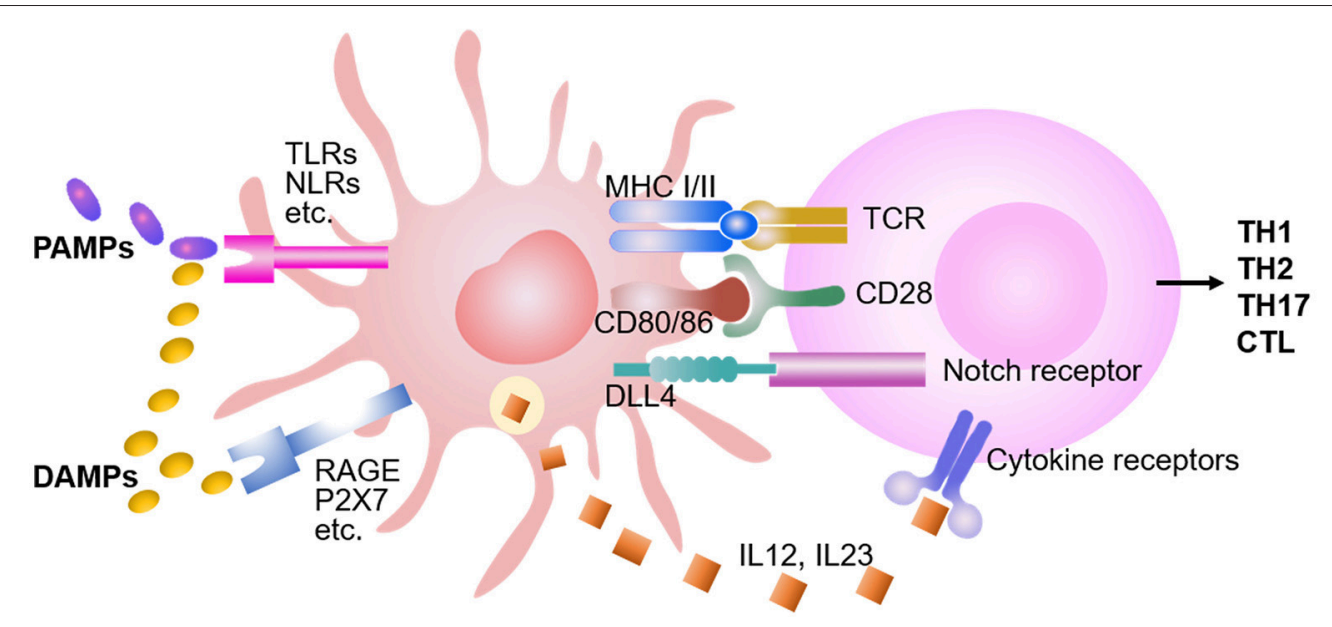

Pro-inflammatory
stimuli

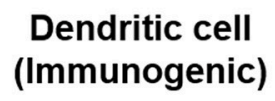

T cell

FIGURE 1 | DC stimulation of allogeneic T cell responses. Preparative conditioning regimens before the allo-HSCT induce host tissue injuries, leading to the release of DAMPs and PAMPs. Consequently, DCs are activated by DAMPs and PAMPs through multiple receptors, capable to present antigens and prime the T cells. While DAMPs activate DCs mainly through TLRs (i.e., TLR 1-13), PAMPs activate DCs through RAGE, P2X7, etc., in addition to the TLRs. Both costimulatory molecules (e.g., CD28) and cytokines (e.g., IL-12, IL-23) synergize with the TCR signaling to promote proliferation and expansion of antigen-activated T cells. DCs also produce higher levels of Notch ligands (e.g., DLL1 and DLL4) to trigger Notch signaling in the T cell, instructing differentiation into distinct lineages of effector cells.

receptor signaling in donor $\mathrm{T}$ cells significantly reduced severity and mortality of GVHD in mouse models (32). Notch-deprived $\mathrm{T}$ cells proliferated and expanded in response to alloantigen in vivo, but failed to produce inflammatory cytokines, including IFN- $\gamma$, IL-17, and TNF- $\alpha(31,32)$. In a separate study, we further observed that host DCs expressing DLL4 (named DLL4 ${ }^{+}$ DCs), one of the ligands of Notch receptors, had greater ability to stimulate the generation of alloreactive effector $\mathrm{T}$ cells that produced IFN- $\gamma$ and IL-17 compared to DLL4 ${ }^{-}$DCs (64-66). Studies by Maillard et al. have shown that blockade of DLL4 could abrogate this effect and prevented GVHD while preserving antitumor activity $(67,68)$. Intriguingly, recent studies demonstrate that chemokine CCL19-expressing host cells, including both fibroblastic reticular cells and follicular DCs, were also the essential source of DLL4 for shaping alloreactive T cell response in mice subject to allo-HSCT (69). Collectively, DC-derived IL-12 and DLL4 are important for the generation of alloreactive effector T cells during GVHD.

\section{Activation of DCs After the Conditioning Regimens for Allo-HSCT}

DCs express pattern recognition receptors (PRRs), such as Toll-like receptors (TLRs), and nod-like receptors (NLRs) to respond to pathogen-associated molecular patterns (PAMPs) (70-72). In addition, DCs are also capable to detect certain intracellular molecules, called damage-associated molecular patterns (DAMPs), that are released from cells stressed, damaged and/or dying in the local tissue (73). When PAMPs or DAMPs are present, DCs are stimulated to migrate to lymphoid tissues and present both antigen and costimulatory molecules to T cells (7375). Preparative conditioning regimens for allo-HSCT, including high-dose chemotherapy and/or total body irradiation, cause host tissue injuries. This leads to the release of proinflammatory cytokines (e.g., TNF- $\alpha$, IL-1 $\beta$, and IL-6) as well as DAMPs and PAMPs $(74,76)$.

Both PAMPs and DAMPs activate DCs through stimulating TLRs (i.e., TLR1-13) (Figure 1) (1, 8, 76-78). TLR expression among DC subsets is heterogeneous: pDC mainly express TLR1, 7 and 9; $\mathrm{CD} 8 \alpha^{+}$DCs preferentially produce high levels of TLR3; whereas other cDC subsets express certain TLR subtypes but TLR9 (73-75, 79-85). Data from our studies and others suggested that Notch ligands DLL1 and DLL4 played nonredundant roles in activating Notch signaling to drive alloreactive $\mathrm{T}$ cell responses $(32,64-66,68)$. LPS (TLR4 agonist) rapidly induces Dll4 expression in human and murine DCs $(65,66,81-$ 83). Combined stimulation of human DCs with LPS with TLR7 agonist R848 further increases the expression of $\operatorname{DLL} 4(65,83)$. TLR3 is critical for presentation of viral double-stranded RNA $(83,86)$. Reddy and colleagues found that TLR3 stimulation enhanced GVL response without exacerbating GVHD in mice (52). These observations explain, at least in part, how different pro-inflammatory stimuli induce distinct types of immune responses.

\section{DC-MEDIATED DONOR T CELL TOLERANCE AGAINST HOST TISSUES}

Self-tolerance can be induced and maintained in different compartments of the immune system. During thymopoietic 
development, self-reactive $\mathrm{T}$ cells are clonally deleted in the thymus as a result of negative selection $(8,23,36,87)$. However, thymopoiesis is impaired during GVHD $(88,89)$, which is associated with generation of alloreactive $\mathrm{T}$ cells that mediate chronic-like GVHD in mice $(90,91)$. Considered as a supplemental mechanism to central tolerance, peripheral tolerance however, is important to prevent autoimmunity (8, $23,36,87)$. DCs are the crucial players mediating peripheral tolerance $(27,36,37,44,87)$. Therefore, we will review the tolerogenic role of DCs in the context of allo-HSCT.

\section{cDCs}

Both host and donor DCs may contribute to the induction of donor $\mathrm{T}$ cell tolerance against host tissues in mice undergoing allo-HSCT. Early studies by Teshima et al. reported that Flt3 ligand (Flt3L) treatment of recipient mice induced expansion of $\mathrm{CD} 8 \alpha^{+}$DCs that were poor stimulators of allogeneic $\mathrm{T}$ cells in cultures and had great ability to suppress donor $\mathrm{T}$ cell responses to host antigens in vivo (Table 1) (41). These Flt3L-treated recipient mice developed much less severe GVHD compared to untreated controls (41). However, whether these in vivo expanded $\mathrm{CD} 8 \alpha^{+}$DCs have direct effects on reducing GVHD was not examined in this study (41). Subsequent studies show that deletion of host $\mathrm{CD}_{11 c^{+}}$cells in CD11c. DTR (diphtheria toxin receptor) transgenic recipient mice caused a strong increase in GVHD-related mortality (50). Since CD11c is also expressed on the surface of some macrophages $(18,19$, 62 ), the possibility that DT treatment might delete $\mathrm{CD} 11 \mathrm{c}^{+}$ macrophages that mediate immune suppression cannot be ruled out. Other studies examined the impact of deleting CD8 $\alpha^{+}$DCs on GVHD development in recipient mice lacking Batf3 (50), which is a transcription factor crucial for the generation of $\mathrm{CD} 8 \alpha^{+}$DCs and migratory CD103 ${ }^{+}$cDCs $(92,93)$. Recipient mice lacking Batf3 developed more severe GVHD compared to WT mice and marked increase of proliferative donor $\mathrm{T}$ cells (50). This finding is further supported independently by studies from Hill and colleagues (51), but not from Reddy's group (52). However, whether transfer of CD8 $\alpha^{+}$DCs may directly suppress GVHD in mice has never been reported. Thus, the exact DC subset induced upon Flt3L treatment capable to reduce GVHD has never been clearly addressed.

\section{pDCs}

The important role of $\mathrm{pDCs}$ in modulating GVH response was initially shown in a mouse model of GVHD. Transfer of host-type CCR9 ${ }^{+}$pDCs inhibited GVHD in mice receiving MHC- or miHA-mismatched donor $\mathrm{T}$ cells (53). CCR9 ${ }^{+}$ pDCs migrate to the GI tract through chemotaxis via their own chemokine receptor CCR9 and the ligand CCL25 in the environment. Upon stimulation with TLR9 agonist CpG ODNs, CCR9 ${ }^{+}$pDCs rapidly downregulate CCR9 from the original immature state and decrease the capacity to attenuate GVHD in vivo (53). Furthermore, precursor pDCs (prepDCs) were found to modulate GVHD in mouse models $(55,56)$. In vivo depletion of pre-pDCs using the antibody specific to PDCA-1, which is expressed on the surface of pDC lineage, significantly increased the severity of GVHD

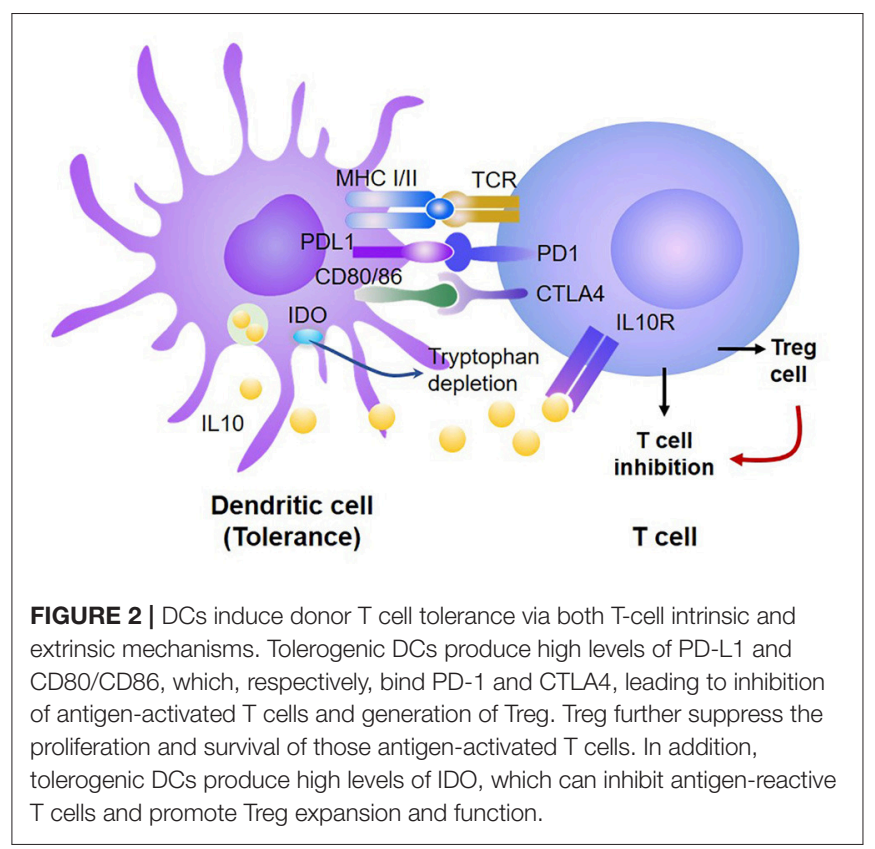

compared to recipient mice with intact donor pre-pDCs (55). Mechanistic analysis reveals that CCR9 ${ }^{+}$pDCs and pre-pDCs are capable to promote Treg expansion and function, as well as to suppress antigen-specific immune responses both in vitro and in vivo $(55,56)$. These observations identify the tolerogenic effect of pDCs on inducing donor T cells against host tissues.

\section{Molecular Mechanisms by Which DCs Induce Donor T Cell Tolerance}

Emerging evidence indicate that the mechanism responsible for DC-induced peripheral $\mathrm{T}$ cell tolerance can be broadly classified into two categories: intrinsic and extrinsic $(18,23,62,87,94)$. T cell intrinsic signal acts directly on the responding $\mathrm{T}$ cells, such as inhibition or deletion of specific T cells, while T cell extrinsic signal acts through additional cells or factors, such as Treg or suppressive cells (Figure 2).

Whether to induce immune activation or tolerance was initially correlated to the maturation state of DCs (62). Immature DCs generated from murine BM induced T cell unresponsiveness in vitro and prolonged cardiac allograft survival $(43,95)$. The immune tolerance induced by immature DCs was associated with their low expression of CD40 (which is essential to activation of $\mathrm{CD}^{+} \mathrm{T}$ cells) and the capacity to produce high levels of IL-10 (which inhibits $\mathrm{T}$ cell response). Probst et al. reported that resting DCs induced peripheral $\mathrm{CD}^{+} \mathrm{T}$ cell tolerance through activating the inhibitory signals PD-1 and CTLA4 on the T cell via PD-L1 and CD80/86, respectively (96-104). Under physiological conditions, these inhibitory molecules keep autoreactive $\mathrm{T}$ cells in check without causing autoimmunity. Blocking either PD-1 or CTLA4 abrogated CD8 ${ }^{+} \mathrm{T}$ cell tolerance induction and enhanced $\mathrm{T}$ cell priming while blocking both resulted in an synergistic effect on inducing $\mathrm{CD}^{+} \mathrm{T}$ cell 
tolerance (96). These observations suggest that DC-derived PD$\mathrm{L} 1$ may promote $\mathrm{T}$ cell tolerance through triggering the T-cell intrinsic mechanism.

Treg and suppressive cells (e.g., myeloid-derived suppressive cells) play crucial roles in establishing and maintaining peripheral tolerance and are known to be important for reducing GVHD (105-108). Waller and colleagues have demonstrated that transfer of donor BM pre-pDCs attenuated GVHD in mice (56). They identified that donor pDCs activated donor T cells to produce IFN- $\gamma$, which then enhanced $\mathrm{pDC}$ synthesis of indoleamine 2,3-dioxygenase (IDO). Increased production of IDO by pDCs altered the balance between donor Treg and alloreactive effector $\mathrm{T}$ cells, thereby limiting the severity of GVHD (56). Other studies showed that GVH reaction also impaired the antigen presentation function of de novo generated donor cDCs, leading to dramatically decreased Treg expansion and function, leading to severe chronic GVHD (109). These observations suggest that reconstitution of tolerogenic DCs from engrafted donor hematopoietic cells may be crucial for preventing the occurrence of severe GVHD.

\section{RECONSTITUTION OF DONOR DCS AFTER ALLO-HSCT}

Clinical studies indicated that impaired reconstitution of donor DCs correlates with the occurrence of severe GVHD (110-115). Wingard and colleagues examined the number of donor DCs in the circulating peripheral blood from a group of 50 allo-HSCT patients. They found that low number of circulating DCs was not only associated with significantly increased risk of relapse and acute GVHD, but also predicative of patient death after allogeneic HSCT (110). Notably, clinical studies from 39 children with alloHSCT indicated that while normal CDC numbers were observed by $300-400$ days after transplantation, pDC numbers were always lower than those of age-matched control patients during the entire follow-up period of up to 7 years (112). In contrast, patients with high pDC recovery profile often had improved overall survival (114). Data from preclinical studies also showed a marked deficit in all lineages of $\mathrm{DCs}\left(\mathrm{CD} 8^{+} \mathrm{DCs}, \mathrm{CD} 11 \mathrm{~b}^{+}\right.$ DCs, and pDCs) in GVHD compared with non-GVHD mice $(55,109,116,117)$. Thus, the recovery of DCs from engrafted HSPCs in allo-HSCT patients may predict the occurrence of severe GVHD and non-relapse mortality.

\section{Donor DCs Mediate Protective Immunity}

DCs are critical for eliciting $\mathrm{T}$ cell immune responses, protecting the host against viral infection $(18,19,118)$. Viral infection remains a major challenge for the success of allo-HSCT. Clinical studies have shown that after allo-HSCT, patients with lower numbers of circulating peripheral blood DCs often have increased risk of infections $(1,110)$. Cytomegalovirus $(\mathrm{CMV})$ is a major cause of post-transplant mortality in patients subject to allo-HSCT, with $\sim 25 \%$ of CMV-seropositive recipients developing CMV-related disease within 3 months after transplantation (119-121). It is well-established that induction of adaptive $\mathrm{T}$ cell immunity is critical to control CMV replication and resolve viral reactivation-mediated disease $(100,122,123)$. cDCs are essential to the generation of effector $\mathrm{T}$ cells reactive to $\mathrm{CMV}$, especially during a primary response. However, GVHD induces a profound DC defect that leads to a failure in the generation of CMV-specific $\mathrm{CD}^{+}{ }^{+} \mathrm{T}$-cells and dramatically decreased antiviral immunity (116). Collectively, improving the reconstitution of DCs following allo-HSCT may represent an effective strategy to re-establish the protective immunity in the recipient. Since $\mathrm{pDCs}$ produce high levels of IL-12 and IFN- $\alpha$ upon activation $(29,124-126)$, improving pDC recovery after allo-HSCT may also provide efficient antiviral immunity.

\section{GVHD Impairs the Generation of DC Progenitors}

GVHD-associated inflammatory responses may influence the reconstitution of donor DCs via a complex mechanism. DCs developed from HSPCs through successive steps of lineage commitment and differentiation: HSCs $\rightarrow$ multiple potent progenitors (MPP) $\rightarrow$ common DC progenitors (CDP) $\rightarrow$ cDCs and pDCs $(22,42,125,127-132)$. Inflammatory cytokines, such as TNF- $\alpha$ and IFN- $\gamma$, directly inhibit the proliferation of HSPCs and their generation of DCs (117). In addition, Matsushima and colleagues have shown that GVHD induced damage to the $\mathrm{BM}$ niche, leading to dramatically decreased hematopoiesis, including the reduction of CDP (133). However, the specific cellular component(s) within the niche that are responsible for the generation of DC progenitors have yet to be determined.

\section{Transcriptional Regulation of DC Development}

The generation of DCs is regulated by a group of functionally distinctive transcription factors (TFs). Analysis of gene-targeted mice has identified many critical TFs in DC development. Some of these TFs, such as Pu.1 and Stat3, influence the generation of all DC subsets. HSPCs lacking Pu.1 showed defective DC differentiation potential $(134,135)$. Targeted deletion of Stat3 impaired the generation of both cDCs and pDCs in vivo (128, 136). Thus, both Pu. 1 and Stat 3 are pioneer TFs in the regulation of DC commitment and differentiation from MPP $(42,128,130)$.

DC subset-specifying TFs are required for committed CDP to become functionally distinct DC lineages $(42,127,128,130)$. For example, Batf3 has a non-redundant role in $\mathrm{CD}_{103}{ }^{+} \mathrm{cDC}$ development and partial effect on inducing $\mathrm{CD} 8 \alpha^{+}$DCs in lymph organs $(52,92,127)$. Irf8-deficient animals lack spleenresident $\mathrm{CD} 8 \alpha^{+} \mathrm{cDCs}$ and nonlymphoid tissue $\mathrm{CD} 103^{+} \mathrm{cDCs}$ $(42,127,137)$. Other TFs, such as Irf4, Klf4, Notch2, and Relb, also play important roles in the regulation of other types of cDCs localized in different tissues $(94,138)$. Among them, Irf4 is required for $\mathrm{cDCs}$ to prime $\mathrm{CD} 4^{+} \mathrm{T}$ cells and promote Th17 differentiation in both the lung and intestine $(60,139)$. In addition, several TFs, such as Tcf4, Irf8, and Spib, are known to regulate pDC differentiation (140-142). The absence of Tcf4 leads to the loss of pDCs in mice (142).

There are limited number of studies investigating how $\mathrm{GVH}$ reactions influence the expression and function of these TFs required for DC development. Notably, a recent 
study revealed that inflammation cascades in $\mathrm{GVH}$ reaction favor the development of $\mathrm{CD}_{103^{+}} \mathrm{D} 11 \mathrm{~b} \mathrm{~b}^{-} \mathrm{DCs}$ in the GI tract (42), which require the presence of functional Irf4 (93). These data indicate that distinct TFs in DCs and their progenitors may have different susceptibility to the regulatory effect of inflammatory environments. This may result in a skewed expression and activation of transcriptional programs, promoting the generation of specific subset(s) of DCs and feed-forward action on alloreactive $\mathrm{T}$ cell responses during the GVHD progression. Delineating the mechanisms underlying this dysregulated donor DC reconstitution during $\mathrm{GVH}$ reaction will be important for understanding the pathophysiology of GVHD and the development of effective treatments for the disease.

\section{MODULATION OF ALLOIMMUNITY}

Manipulation of DC precursors in the HSPC graft may facilitate the establishment of a balance between GVHD and GVL effects $(2,9,16,34,35,56)$. Preclinical studies have shown that transfer of donor pre-pDCs derived from donor mice treated with Flt3L induced markedly augmented GVL activity of donor $\mathrm{T}$ cells without aggravating GVHD (56). These donor prepDCs persisted long in that they expanded in vivo for 2 weeks after transplantation (56). These findings perfectly supported the clinical value of donor DCs in modulating alloimmunity to improve the efficacy and safety of allo-HSCT.

\section{Use of Tolerogenic DCs to Reduce GVHD}

The capacity of DCs to induce tolerance has led to numerous therapeutic studies using these cells in an effort to control harmful immune responses in models of allograft rejection, GVHD and autoimmune disorders $(18,27,34,36,37,62$, $87,143)$. While transfer of immature CCR9 ${ }^{+}$pDCs reduced GVHD, transfer of mature donor pDCs did not as expected (144). Furthermore, transfer of highly purified immature pDCs derived from donors was technically challenging and typically required in vivo expansion step to generate the number enough for modulating GVH reaction in vivo $(53,56,144)$.

With this technical bottle neck, many studies had to assess the therapeutic effect of ex-vivo-generated DCs. Tolerogenic DCs were tried to be generated through propagating human monocytes in vitro in the presence of various agents, such as IL-10, Vitamin D3, and immunosuppressive drugs (e.g., dexamethasone and rapamycin) $(34,36,37,87,143)$. Yet, none of the approaches generated the best clinically applicable DCs with the expected tolerogenic capacity to modulate alloreactive $\mathrm{T}$ cells $(34,36,37,87,143)$. Reddy and colleagues report that upon pre-treatment with the HDAC inhibitor SAHA, these moDCs produced high levels of IDO and promoted Treg expansion and function in vivo, leading to attenuated GVHD in mice (54). These findings indicate that targeting epigenetic regulators in DCs may prove to be an effective strategy to induce the generation of DCs with tolerogenic properties for reducing GVHD.

\section{Induction of GVL Effects After Allo-HSCT}

Emerging evidence indicated that DCs were required for optimal GVL response without aggravating GVHD. Reddy and colleagues report that as compared to allogeneic wild-type (WT) hosts, allogeneic Batf3-deficient recipient mice developed severe GVHD but with significantly reduced GVL response (52). This indicates the importance of $\mathrm{CD} 8 \alpha^{+}$DCs in GVL response. Indeed, co-transfer of WT host-type spleen DCs (which contain $\left.\mathrm{CD} 8 \alpha^{+} \mathrm{DCs}\right)$ and $\mathrm{T}$ cells into allogeneic $\mathrm{B} 2 \mathrm{~m}^{-/-}$recipients, which are functionally deficient in antigen presentation, induced a significant $\mathrm{CD}^{+} \mathrm{T}$ cell-mediated GVL response, leading to prolonged survival of recipients without tumor. In contrast, all of the $\mathrm{B} 2 \mathrm{~m}^{-/-}$mice receiving Batf3 $3^{-/-}$spleen DCs, which lack CD8 $\alpha^{+}$DCs (92), died from tumor despite the presence of other DC subsets (52). This confirms the crucial role of CD $8 \alpha^{+}$DCs in eliciting anti-tumor immunity. However, these experiments did not examine the direct effect of CD8 $\alpha^{+}$DCs on T cell-mediated GVL response.

In human recipients of unrelated donor BM grafts, but not granulocyte colony-stimulating factor (G-CSF)-mobilized peripheral blood grafts, a higher number of donor pDCs is associated with increased survival and reduced GVHD (145). Data from experimental studies indicate that transfer of pDCenriched BM grafts preserved GVL effects without aggravating GVHD in mice $(56,146)$. pDCs produce high levels of IFN- $\alpha$ and IL-12 $(147,148)$, cytokines important to promote differentiation and expansion of antigen-specific effector cells (149). In these studies, Waller and colleagues have demonstrated that in vivo administration of Flt3L to donor mice induced 5-fold increase in $\mathrm{pDC}$ content without significant changes in the number of HSCs, T cells and B cells. Most importantly, transfer of pDCenriched BM graft from Flt3L-treated donors decreased GVHD while retaining GVL effects in allogeneic recipient mice (146).

We have recently established a novel platform to produce Dll4 ${ }^{+}$DCs from murine BM using Flt3L and TLR agonists (64). Upon allogeneic Dll4 ${ }^{+}$DC stimulation, $\mathrm{CD}^{+}$naïve $\mathrm{T}$ cells underwent effector differentiation and produced high levels of IFN- $\gamma$ and IL-17 in vitro, depending on Dll4 activation of Notch signaling. Adoptive transfer of these Dll4 ${ }^{+} \mathrm{DC}$-induced T cells eliminated leukemic cells without causing severe GVHD, leading to significantly improved survival of leukemic mice undergoing allo-HSCT. This strategy may potentially improve the antileukemic response after HSCT and overcome some barriers to the GVL response such as high disease burden and pharmacologic immunosuppression (64). Since DC activation of naïve T cells allows them to be primed with antigens, Dll4 ${ }^{+}$DCs loaded with leukemia-associated antigens may facilitate the selective expansion of leukemic cell-reactive T cells and specifically boost the anti-leukemia activity.

\section{CONCLUSION}

While traditional therapies have been targeting $\mathrm{T}$ cells, extensive research in murine HSCT models convincingly showed the ability of DCs to preserve GVL response without aggravating GVHD. 
Targeting donor DCs in vivo or ex vivo may potentially subvert alloreactive T cell responses and reduce GVHD (53). Given the role of DCs in maintaining Treg after allo-HSCT $(56,109)$, cotransfer of tolerogenic DCs and Treg could be more effective on reducing GVH reactions in vivo. A randomized Phase I study has shown the safety of infusing the host tolerogenic DCs into diabetes patients (150). It will be interesting to test whether these ex vivo generated tolerogenic DCs given in the peritransplant period may prevent GVHD while preserving GVL effects.

One major challenge is to produce large number of donor-type tolerogenic DCs that can persist sufficient time to execute their function following adoptive transfer to modulate alloimmunity. We propose that donor-type DCs have several advantages compared to host-type DCs. For example, donors are healthy, and their hematopoietic system is not compromised by accompanied disease state and treatment conditions. Furthermore, available data from both clinical and pre-clinical studies suggest that donor-derived pDCs have potent capability to modulate $\mathrm{GVH}$ reactions $(55,56,145,146)$. These

\section{REFERENCES}

1. Zeiser R, Blazar BR. Acute graft-versus-host disease - biologic process, prevention, and therapy. N Engl J Med. (2017) 377:2167-79. doi: 10.1056/NEJMra1609337

2. Choi SW, Reddy P. Current and emerging strategies for the prevention of graft-versus-host disease. Nat Rev Clin Oncol. (2014) 11:536-47. doi: $10.1038 /$ nrclinonc.2014.102

3. Dickinson AM, Norden J, Li S, Hromadnikova I, Schmid C, Schmetzer $\mathrm{H}$, et al. Graft-versus-leukemia effect following hematopoietic stem cell transplantation for leukemia. Front Immunol. (2017) 8:496. doi: $10.3389 /$ fimmu.2017.00496

4. Kolb HJ, Schmid C, Barrett AJ, Schendel DJ. Graft-versus-leukemia reactions in allogeneic chimeras. Blood (2004) 103:767-776. doi: 10.1182/blood-2003-02-0342

5. Wu CJ, Ritz J. Induction of tumor immunity following allogeneic stem cell transplantation. Adv Immunol. (2006) 90:133-73. doi: 10.1016/S0065-2776(06)90004-2

6. Ruutu T, Gratwohl A, de Witte T, Afanasyev B, Apperley J, Bacigalupo A, et al. Prophylaxis and treatment of GVHD: EBMTELN working group recommendations for a standardized practice. Bone Marrow Transplant. (2014) 49:168-73. doi: 10.1038/bmt.20 13.107

7. Hamadani M, Hofmeister CC, Jansak B, Phillips G, Elder P, Blum $\mathrm{W}$, et al. Addition of infliximab to standard acute graft-versushost disease prophylaxis following allogeneic peripheral blood cell transplantation. Biol Blood Marrow Transplant J Am Soc Blood Marrow Transplant. (2008) 14:783-9. doi: 10.1016/j.bbmt.2008. 04.006

8. Blazar BR, Murphy WJ, Abedi M. Advances in graft-versus-host disease biology and therapy. Nat Rev Immunol. (2012) 12:443-58. doi: $10.1038 /$ nri3212

9. Shlomchik WD. Graft-versus-host disease. Nat Rev Immunol. (2007) 7:34052. doi: $10.1038 /$ nri2000

10. Matte CC, Liu J, Cormier J, Anderson BE, Athanasiadis I, Jain D, et al. Donor APCs are required for maximal GVHD but not for GVL. Nat Med. (2004) 10:987-92. doi: 10.1038/nm1089

11. Zhang Y, Shlomchik WD, Joe G, Louboutin JP, Zhu J, Rivera A, et al. APCs in the liver and spleen recruit activated allogeneic CD8 $+\mathrm{T}$ cells to elicit hepatic graft-versus-host disease. J Immunol. (2002) 169:7111-8. doi: 10.4049/jimmunol.169.12.7111 data provide a proof of concept that in vivo administration of pDCs is promising for enhancing GVL response without causing severe GVHD.

Most recent studies have shown that the fate of $\mathrm{pDCs}$ is determined early at the stage of HSCs $(127,130,136,151-$ 153). This suggests that induction of tolerogenic DCs should start from the HSPC stage. Better understanding how the fate of tolerogenic DCs are determined and regulated may have significant implication in the production of DCs for efficiently modulating alloimmunity.

\section{AUTHOR CONTRIBUTIONS}

HY, YT, YW, SM, and YZ collected all materials for reviewing and wrote the review.

\section{ACKNOWLEDGMENTS}

This work was supported by Department of Defense (YZ) and NIH (CA172106-01, YZ, HL127351-01A1, YZ).

12. Shlomchik WD, Couzens MS, Tang CB, McNiff J, Robert ME, Liu J, et al. Prevention of graft versus host disease by inactivation of host antigenpresenting cells. Science (1999) 285:412-5. doi: 10.1126/science.285.5426.412

13. Koyama M, Cheong M, Markey KA, Gartlan KH, Kuns RD, Locke $\mathrm{KR}$, et al. Donor colonic CD103+ dendritic cells determine the severity of acute graft-versus-host disease. J Exp Med. (2015) 212:1303-21. doi: $10.1084 /$ jem. 20150329

14. Koyama M, Kuns RD, Olver SD, Raffelt NC, Wilson YA, Don AL, et al. Recipient nonhematopoietic antigen-presenting cells are sufficient to induce lethal acute graft-versus-host disease. Nat Med. (2011) 18:135-42. doi: $10.1038 / \mathrm{nm} .2597$

15. Tawara I, Shlomchik WD, Jones A, Zou W, Nieves E, Liu C, et al. A crucial role for host APCs in the induction of donor $\mathrm{CD} 4+\mathrm{CD} 25+$ regulatory $\mathrm{T}$ cellmediated suppression of experimental graft-versus-host disease. J Immunol. (2010) 185:3866-72. doi: 10.4049/jimmunol.1001625

16. Reddy P, Maeda Y, Liu C, Krijanovski OI, Korngold R, Ferrara JL. A crucial role for antigen-presenting cells and alloantigen expression in graft-versusleukemia responses. Nat Med. (2005) 11:1244-9. doi: 10.1038/nm1309

17. Teshima T, Ordemann R, Reddy P, Gagin S, Liu C, Cooke KR, et al. Acute graft-versus-host disease does not require alloantigen expression on host epithelium. Nat Med. (2002) 8:575-81. doi: 10.1038/nm0602-575

18. Steinman RM, Banchereau J. Taking dendritic cells into medicine. Nature (2007) 449:419-26. doi: 10.1038/nature06175

19. Banchereau J, Steinman RM. Dendritic cells and the control of immunity. Nature (1998) 392:245-52. doi: 10.1038/32588

20. Zamvil SS, Steinman L. The $\mathrm{T}$ lymphocyte in experimental allergic encephalomyelitis. Annu Rev Immunol. (1990) 8:579-621. doi: 10.1146/annurev.iy.08.040190.003051

21. Naik SH. Demystifying the development of dendritic cell subtypes, a little. Immunol Cell Biol. (2008) 86:439-52. doi: 10.1038/icb.2008.28

22. Shortman K, Naik SH. Steady-state and inflammatory dendritic-cell development. Nat Rev Immunol. (2007) 7:19-30. doi: 10.1038/nri1996

23. Reizis B, Colonna M, Trinchieri G, Barrat F, Gilliet M. Plasmacytoid dendritic cells: one-trick ponies or workhorses of the immune system? Nat Rev Immunol. (2011) 11:558-65. doi: 10.1038/nri3027

24. Zuniga EI, McGavern DB, Pruneda-Paz JL, Teng C, Oldstone MB. Bone marrow plasmacytoid dendritic cells can differentiate into myeloid dendritic cells upon virus infection. Nat Immunol. (2004) 5:1227-34. doi: $10.1038 /$ nil136

25. Schlitzer A, Loschko J, Mair K, Vogelmann R, Henkel L, Einwachter H, et al. Identification of CCR9- murine plasmacytoid DC precursors with 
plasticity to differentiate into conventional DCs. Blood (2011) 117:6562-70. doi: 10.1182/blood-2010-12-326678

26. Strioga MM, Felzmann T, Powell DJ, Jr., Ostapenko V, Dobrovolskiene NT, Matuskova M, et al. Therapeutic dendritic cell-based cancer vaccines: the state of the art. Crit Rev Immunol. (2013) 33:489-547. doi: 10.1615/CritRevImmunol.2013008033

27. Palucka K, Banchereau J. Dendritic-cell-based therapeutic cancer vaccines. Immunity (2013) 39:38-48. doi: 10.1016/j.immuni.2013.07.004

28. Collin M, McGovern N, Haniffa M. Human dendritic cell subsets. Immunology (2013) 140:22-30. doi: 10.1111/imm.12117

29. Colonna M, Trinchieri G, Liu YJ. Plasmacytoid dendritic cells in immunity. Nat Immunol. (2004) 5:1219-26. doi: 10.1038/ni1141

30. Benlahrech A, Duraisingham S, King D, Verhagen L, Rozis G, Amjadi P, et al. Human blood CD1c dendritic cells stimulate IL-12-independent IFNgamma responses and have a strikingly low inflammatory profile. J Leukocyte Biol. (2015) 97:873-85. doi: 10.1189/jlb.1A0114-058RR

31. Sandy AR, Chung J, Toubai T, Shan GT, Tran IT, Friedman A, et al. T cell-specific notch inhibition blocks graft-versus-host disease by inducing a hyporesponsive program in alloreactive CD4+ and CD8 $+\mathrm{T}$ cells. $J$ Immunol. (2013) 190:5818-28. doi: 10.4049/jimmunol.1203452

32. Zhang Y, Sandy AR, Wang J, Radojcic V, Shan GT, Tran IT, et al. Notch signaling is a critical regulator of allogeneic CD4+ T-cell responses mediating graft-versus-host disease. Blood (2011) 117:299-308. doi: 10.1182/blood-2010-03-271940

33. Amsen D, Antov A, Flavell RA. The different faces of Notch in T-helper-cell differentiation. Nat Rev Immunol. (2009) 9:116-24. doi: 10.1038/nri2488

34. Stenger EO, Turnquist HR, Mapara MY, Thomson AW. Dendritic cells and regulation of graft-versus-host disease and graft-versus-leukemia activity. Blood (2012) 119:5088-103. doi: 10.1182/blood-2011-11-364091

35. MacDonald KP, Shlomchik WD, Reddy P. Biology of graft-versus-host responses: recent insights. Biol Blood Marrow Transplant J Am Soc Blood Marrow Transplant. (2013) 19:S10-14. doi: 10.1016/j.bbmt.2012.11.005

36. Audiger C, Rahman MJ, Yun TJ, Tarbell KV, Lesage S. The importance of dendritic cells in maintaining immune tolerance. J Immunol. (2017) 198:2223-31. doi: 10.4049/jimmunol.1601629

37. Devi KS, Anandasabapathy N. The origin of DCs and capacity for immunologic tolerance in central and peripheral tissues. Semin Immunopathol. (2017) 39:137-52. doi: 10.1007/s00281-016-0602-0

38. Fugier-Vivier IJ, Rezzoug F, Huang Y, Graul-Layman AJ, Schanie CL, $\mathrm{Xu} \mathrm{H}$, et al. Plasmacytoid precursor dendritic cells facilitate allogeneic hematopoietic stem cell engraftment. J Exp Med. (2005) 201:373-83. doi: 10.1084/jem.20041399

39. Cardenas PA, Huang Y, Ildstad ST. The role of pDC, recipient T(reg) and donor T(reg) in HSC engraftment: mechanisms of facilitation. Chimerism (2011) 2:65-70. doi: 10.4161/chim.17588

40. Merad M, Hoffmann P, Ranheim E, Slaymaker S, Manz MG, Lira SA, et al. Depletion of host Langerhans cells before transplantation of donor alloreactive T cells prevents skin graft-versus-host disease. Nat Med. (2004) 10:510-7. doi: 10.1038/nm1038

41. Teshima T, Reddy P, Lowler KP, KuKuruga MA, Liu C, Cooke KR, et al. Flt3 ligand therapy for recipients of allogeneic bone marrow transplants expands host CD8 alpha $(+)$ dendritic cells and reduces experimental acute graftversus-host disease. Blood (2002) 99:1825-32. doi: 10.1182/blood.V99.5.1825

42. Merad M, Sathe P, Helft J, Miller J, Mortha A. The dendritic cell lineage: ontogeny and function of dendritic cells and their subsets in the steady state and the inflamed setting. Annu Rev Immunol. (2013) 31:563-604. doi: 10.1146/annurev-immunol-020711-074950

43. Morelli AE, Thomson AW. Tolerogenic dendritic cells and the quest for transplant tolerance. Nat Rev Immunol. (2007) 7:610-21. doi: $10.1038 /$ nri2132

44. Chung CY, Ysebaert D, Berneman ZN, Cools N. Dendritic cells: cellular mediators for immunological tolerance. Clin Dev Immunol. (2013) 2013:972865. doi: 10.1155/2013/972865

45. Chakraverty R, Sykes M. The role of antigen-presenting cells in triggering graft-versus-host disease and graft-versus-leukemia. Blood (2007) 110:9-17. doi: 10.1182/blood-2006-12-022038

46. Zhang Y, Louboutin JP, Zhu J, Rivera AJ, Emerson SG. Preterminal host dendritic cells in irradiated mice prime CD8+ $\mathrm{T}$ cell-mediated acute graft-versus-host disease. J Clin Invest. (2002) 109:1335-44. doi: 10.1172/JCI0214989

47. Koyama M, Hashimoto D, Aoyama K, Matsuoka K, Karube K, Niiro H, et al. Plasmacytoid dendritic cells prime alloreactive T cells to mediate graftversus-host disease as antigen-presenting cells. Blood (2009) 113:2088-95. doi: 10.1182/blood-2008-07-168609

48. Li H, Kaplan DH, Matte-Martone C, Tan HS, Venkatesan S, Johnson K, et al. Langerhans cells are not required for graft-versus-host disease. Blood (2011) 117:697-707. doi: 10.1182/blood-2010-07-299073

49. Markey KA, Banovic T, Kuns RD, Olver SD, Don AL, Raffelt NC, et al. Conventional dendritic cells are the critical donor APC presenting alloantigen after experimental bone marrow transplantation. Blood (2009) 113:5644-9. doi: 10.1182/blood-2008-12-191833

50. Weber M, Rudolph B, Stein P, Yogev N, Bosmann M, Schild H, et al. Host-derived CD8 $(+)$ dendritic cells protect against acute graft-versushost disease after experimental allogeneic bone marrow transplantation. Biol Blood Marrow Transplant J Am Soc Blood Marrow Transplant. (2014) 20:1696-704. doi: 10.1016/j.bbmt.2014.08.005

51. Markey KA, Kuns RD, Browne DJ, Gartlan KH, Robb RJ, Martins JP, et al. Flt-3L expansion of recipient CD8alpha $(+)$ dendritic cells deletes alloreactive donor $\mathrm{T}$ cells and represents an alternative to posttransplant cyclophosphamide for the prevention of GVHD. Clin Cancer Res Offic J Am Assoc Cancer Res. (2018) 24:1604-16. doi: 10.1158/1078-0432.CCR-17-2148

52. Toubai T, Sun Y, Luker G, Liu J, Luker KE, Tawara I, et al. Host-derived $\mathrm{CD} 8+$ dendritic cells are required for induction of optimal graft-versustumor responses after experimental allogeneic bone marrow transplantation. Blood (2013) 121:4231-41. doi: 10.1182/blood-2012-05-432872

53. Hadeiba H, Sato T, Habtezion A, Oderup C, Pan J, Butcher EC. CCR9 expression defines tolerogenic plasmacytoid dendritic cells able to suppress acute graft-versus-host disease. Nat Immunol. (2008) 9:1253-60. doi: $10.1038 /$ ni. 1658

54. Reddy P, Sun Y, Toubai T, Duran-Struuck R, Clouthier SG, Weisiger E, et al. Histone deacetylase inhibition modulates indoleamine 2,3-dioxygenasedependent DC functions and regulates experimental graft-versus-host disease in mice. J Clin Invest. (2008) 118:2562-73. doi: 10.1172/JCI 34712

55. Banovic T, Markey KA, Kuns RD, Olver SD, Raffelt NC, Don AL, et al. Graftversus-host disease prevents the maturation of plasmacytoid dendritic cells. J Immunol. (2009) 182:912-20. doi: 10.4049/jimmunol.182.2.912

56. Lu Y, Giver CR, Sharma A, Li JM, Darlak KA, Owens LM, et al. IFN-gamma and indoleamine 2,3-dioxygenase signaling between donor dendritic cells and $\mathrm{T}$ cells regulates graft versus host and graft versus leukemia activity. Blood (2012) 119:1075-85. doi: 10.1182/blood-2010-12-32 2891

57. Rowe V, Banovic T, MacDonald KP, Kuns R, Don AL, Morris ES, et al. Host B cells produce IL-10 following TBI and attenuate acute GVHD after allogeneic bone marrow transplantation. Blood (2006) 108:2485-92. doi: 10.1182/blood-2006-04-016063

58. Haniffa M, Ginhoux F, Wang XN, Bigley V, Abel M, Dimmick I, et al. Differential rates of replacement of human dermal dendritic cells and macrophages during hematopoietic stem cell transplantation. J Exp Med. (2009) 206:371-85. doi: 10.1084/jem.20081633

59. Jones SC, Murphy GF, Friedman TM, Korngold R. Importance of minor histocompatibility antigen expression by nonhematopoietic tissues in a CD4+ T cell-mediated graft-versus-host disease model. J Clin Invest. (2003) 112:1880-6. doi: 10.1172/JCI19427

60. Vander Lugt B, Khan AA, Hackney JA, Agrawal S, Lesch J, Zhou M, et al. Transcriptional programming of dendritic cells for enhanced MHC class II antigen presentation. Nat Immunol. (2014) 15:161-7. doi: 10.1038/ni.2795

61. Yao S, Buzo BF, Pham D, Jiang L, Taparowsky EJ, Kaplan MH, et al. Interferon regulatory factor 4 sustains $\mathrm{CD} 8(+) \mathrm{T}$ cell expansion and effector differentiation. Immunity (2013) 39:833-45. doi: 10.1016/j.immuni.2013.10.007

62. Steinman RM, Hawiger D, Nussenzweig MC. Tolerogenic dendritic cells. Annu Rev Immunol. (2003) 21:685-711. doi: 10.1146/annurev.immunol.21.120601.141040

63. Xia S, Guo Z, Xu X, Yi H, Wang Q, Cao X. Hepatic microenvironment programs hematopoietic progenitor differentiation into regulatory 
dendritic cells, maintaining liver tolerance. Blood (2008) 112:3175-85. doi: 10.1182/blood-2008-05-159921

64. Mochizuki K, Meng L, Mochizuki I, Tong Q, He S, Liu Y, et al. Programming of donor T cells using allogeneic delta-like ligand 4-positive dendritic cells to reduce GVHD in mice. Blood (2016) 127:3270-80. doi: 10.1182/blood-2015-05-644476

65. Meng L, Bai Z, He S, Mochizuki K, Liu Y, Purushe J, et al. The notch ligand DLL4 defines a capability of human dendritic cells in regulating Th1 and Th17 differentiation. J Immunol. (2016) 196:1070-80. doi: 10.4049/jimmunol.1501310

66. Mochizuki K, Xie F, He S, Tong Q, Liu Y, Mochizuki I, et al. Delta-like ligand 4 identifies a previously uncharacterized population of inflammatory dendritic cells that plays important roles in eliciting allogeneic T cell responses in mice. J Immunol. (2013) 190:3772-82. doi: $10.4049 /$ jimmunol.1202820

67. Ting HA, Schaller MA, de Almeida Nagata DE, Rasky AJ, Maillard IP, Lukacs NW. Notch ligand delta-like 4 promotes regulatory $\mathrm{T}$ cell identity in pulmonary viral infection. J Immunol. (2017) 198:1492-502. doi: 10.4049/jimmunol.1601654

68. Tran IT, Sandy AR, Carulli AJ, Ebens C, Chung J, Shan GT, et al. Blockade of individual Notch ligands and receptors controls graftversus-host disease. J Clin Invest. (2013) 123:1590-604. doi: 10.1172/JCI 65477

69. Chung J, Ebens CL, Perkey E, Radojcic V, Koch U, Scarpellino L, et al. Fibroblastic niches prime $\mathrm{T}$ cell alloimmunity through Delta-like Notch ligands. J Clin Invest. (2017) 127:1574-88. doi: 10.1172/JCI89535

70. Iwasaki A, Medzhitov R. Regulation of adaptive immunity by the innate immune system. Science (2010) 327:291-5. doi: 10.1126/science.1183021

71. Janeway C. Immunogenicity signals $1,2,3 \ldots$ and 0 . Immunol Today (1989) 10:283-6. doi: 10.1016/0167-5699(89)90081-9

72. Krishnaswamy JK, Chu T, Eisenbarth SC. Beyond pattern recognition: NOD-like receptors in dendritic cells. Trends Immunol. (2013) 34:224-33. doi: 10.1016/j.it.2012.12.003

73. Seong SY, Matzinger P. Hydrophobicity: an ancient damage-associated molecular pattern that initiates innate immune responses. Nat Rev Immunol. (2004) 4:469-78. doi: 10.1038/nri1372

74. Akira S, Uematsu S, Takeuchi O. Pathogen recognition and innate immunity. Cell (2006) 124:783-801. doi: 10.1016/j.cell.2006.02.015

75. Kono H, Rock KL. How dying cells alert the immune system to danger. Nat Rev Immunol. (2008) 8:279-89. doi: 10.1038/nri2215

76. Ferrara JL, Levine JE, Reddy P, Holler E. Graft-versus-host disease. Lancet (2009) 373:1550-61. doi: 10.1016/S0140-6736(09)60237-3

77. Wilhelm K, Ganesan J, Muller T, Durr C, Grimm M, Beilhack A, et al. Graftversus-host disease is enhanced by extracellular ATP activating P2X7R. Nat Med. (2010) 16:1434-8. doi: 10.1038/nm.2242

78. Jankovic D, Ganesan J, Bscheider M, Stickel N, Weber FC, Guarda G, et al. The Nlrp3 inflammasome regulates acute graft-versus-host disease. J Exp Med. (2013) 210:1899-910. doi: 10.1084/jem.20130084

79. Amsen D, Blander JM, Lee GR, Tanigaki K, Honjo T, Flavell RA. Instruction of distinct $\mathrm{CD} 4 \mathrm{~T}$ helper cell fates by different notch ligands on antigen-presenting cells. Cell (2004) 117:515-26. doi: 10.1016/S0092-8674(04)00451-9

80. Mukherjee S, Schaller MA, Neupane R, Kunkel SL, Lukacs NW. Regulation of $\mathrm{T}$ cell activation by Notch ligand, DLL4, promotes IL17 production and Rorc activation. J Immunol. (2009) 182:7381-8. doi: $10.4049 /$ jimmunol.0804322

81. Yamaguchi E, Chiba S, Kumano K, Kunisato A, Takahashi T, Takahashi T, et al. Expression of Notch ligands, Jagged1:2 and Delta1 in antigen presenting cells in mice. Immunol Lett. (2002) 81:59-64. doi: 10.1016/S0165-2478(01)00326-1

82. Tan AM, Chen HC, Pochard P, Eisenbarth SC, Herrick CA, Bottomly HK. TLR4 signaling in stromal cells is critical for the initiation of allergic Th2 responses to inhaled antigen. J Immunol. (2010) 184:3535-44. doi: 10.4049/jimmunol.0900340

83. Napolitani G, Rinaldi A, Bertoni F, Sallusto F, Lanzavecchia A. Selected Toll-like receptor agonist combinations synergistically trigger a $\mathrm{T}$ helper type 1-polarizing program in dendritic cells. Nat Immunol. (2005) 6:769-76. doi: $10.1038 /$ ni1223
84. Schaller MA, Neupane R, Rudd BD, Kunkel SL, Kallal LE, Lincoln P, et al. Notch ligand Delta-like 4 regulates disease pathogenesis during respiratory viral infections by modulating Th2 cytokines. J Exp Med. (2007) 204:292534. doi: 10.1084 /jem. 20070661

85. Skokos D, Nussenzweig MC. CD8- DCs induce IL-12-independent Th1 differentiation through Delta 4 Notch-like ligand in response to bacterial LPS. J Exp Med. (2007) 204:1525-31. doi: 10.1084/jem.20062305

86. Spranger S, Frankenberger B, Schendel DJ. NOD/scid IL-2Rg(null) mice: a preclinical model system to evaluate human dendritic cell-based vaccine strategies in vivo. J Transl Med. (2012) 10:30. doi: 10.1186/1479-5876-10-30

87. Ganguly D, Haak S, Sisirak V, Reizis B. The role of dendritic cells in autoimmunity. Nat Rev Immunol. (2013) 13:566-77. doi: 10.1038/nri3477

88. Na IK, Lu SX, Yim NL, Goldberg GL, Tsai J, Rao U, et al. The cytolytic molecules Fas ligand and TRAIL are required for murine thymic graftversus-host disease. J Clin Invest. (2010) 120:343-56. doi: 10.1172/JCI39395

89. van den Brink MR, Moore E, Ferrara JL, Burakoff SJ. Graft-versushost-disease-associated thymic damage results in the appearance of $\mathrm{T}$ cell clones with anti-host reactivity. Transplantation (2000) 69:446-9. doi: 10.1097/00007890-200002150-00026

90. Zhang Y, Hexner E, Frank D, Emerson SG. CD4+ T cells generated de novo from donor hemopoietic stem cells mediate the evolution from acute to chronic graft-versus-host disease. J Immunol. (2007) 179:3305-14. doi: 10.4049/jimmunol.179.5.3305

91. Teshima T, Reddy P, Liu C, Williams D, Cooke KR, Ferrara JL. Impaired thymic negative selection causes autoimmune graft-versus-host disease. Blood (2003) 102:429-35. doi: 10.1182/blood-2003-01-0266

92. Hildner K, Edelson BT, Purtha WE, Diamond M, Matsushita $\mathrm{H}$, Kohyama M, et al. Batf3 deficiency reveals a critical role for CD8alpha+ dendritic cells in cytotoxic T cell immunity. Science (2008) 322:1097-100. doi: $10.1126 /$ science. 1164206

93. Murphy KM. Transcriptional control of dendritic cell development. $A d v$ Immunol. (2013) 120:239-67. doi: 10.1016/B978-0-12-417028-5.00009-0

94. Price JD, Tarbell KV. The role of dendritic cell subsets and innate immunity in the pathogenesis of type 1 diabetes and other autoimmune diseases. Front Immunol. (2015) 6:288. doi: 10.3389/fimmu.2015.00288

95. O'Connell PJ, Li W, Wang Z, Specht SM, Logar AJ, Thomson AW. Immature and mature CD8alpha+ dendritic cells prolong the survival of vascularized heart allografts. J Immunol. (2002) 168:143-54. doi: 10.4049/jimmunol.168.1.143

96. Probst HC, McCoy K, Okazaki T, Honjo T, van den Broek M. Resting dendritic cells induce peripheral CD8 $+\mathrm{T}$ cell tolerance through PD-1 and CTLA-4. Nat Immunol. (2005) 6:280-6. doi: 10.1038/ni1165

97. Robert C, Ribas A, Wolchok JD, Hodi FS, Hamid O, Kefford R, et al. Anti-programmed-death-receptor-1 treatment with pembrolizumab in ipilimumab-refractory advanced melanoma: a randomised dosecomparison cohort of a phase 1 trial. Lancet (2014) 384:1109-17. doi: 10.1016/S0140-6736(14)60958-2

98. Franceschini D, Paroli M, Francavilla V, Videtta M, Morrone S, Labbadia G, et al. PD-L1 negatively regulates CD4+CD25+Foxp3+ Tregs by limiting STAT-5 phosphorylation in patients chronically infected with HCV. J Clin Invest. (2009) 119:551-64. doi: 10.1172/JCI36604

99. Keir ME, Butte MJ, Freeman GJ, Sharpe AH. PD-1 and its ligands in tolerance and immunity. Annu Rev Immunol. (2008) 26:677-704. doi: 10.1146/annurev.immunol.26.021607.090331

100. Wherry EJ, Ha SJ, Kaech SM, Haining WN, Sarkar S, Kalia V, et al. Molecular signature of CD8+ $\mathrm{T}$ cell exhaustion during chronic viral infection. Immunity (2007) 27:670-84. doi: 10.1016/j.immuni.2007.09.006

101. Blazar BR, Carreno BM, Panoskaltsis-Mortari A, Carter L, Iwai Y, Yagita H, et al. Blockade of programmed death-1 engagement accelerates graft-versushost disease lethality by an IFN-gamma-dependent mechanism. J Immunol. (2003) 171:1272-7. doi: 10.4049/jimmunol.171.3.1272

102. Tseng SY, Otsuji M, Gorski K, Huang X, Slansky JE, Pai SI, et al. B7-DC, a new dendritic cell molecule with potent costimulatory properties for $\mathrm{T}$ cells. J Exp Med. (2001) 193:839-46. doi: 10.1084/jem.193.7.839

103. Vanasek TL, Khoruts A, Zell T, Mueller DL. Antagonistic roles for CTLA-4 and the mammalian target of rapamycin in the regulation of clonal anergy: enhanced cell cycle progression promotes recall antigen responsiveness. $J$ Immunol. (2001) 167:5636-44. doi: 10.4049/jimmunol.167.10.5636 
104. Tamura H, Dong H, Zhu G, Sica GL, Flies DB, Tamada K, et al. B7-H1 costimulation preferentially enhances CD28-independent Thelper cell function. Blood (2001) 97:1809-16. doi: 10.1182/blood.V97. 6.1809

105. Beilhack A, Schulz S, Baker J, Beilhack GF, Nishimura R, Baker EM, et al. Prevention of acute graft-versus-host disease by blocking Tcell entry to secondary lymphoid organs. Blood (2008) 111:2919-28. doi: 10.1182/blood-2007-09-112789

106. Nguyen VH, Zeiser R, Dasilva DL, Chang DS, Beilhack A, Contag $\mathrm{CH}$, et al. In vivo dynamics of regulatory $\mathrm{T}$-cell trafficking and survival predict effective strategies to control graft-versus-host disease following allogeneic transplantation. Blood (2007) 109:2649-56. doi: 10.1182/blood-2006-08-044529

107. Edinger M, Hoffmann P, Ermann J, Drago K, Fathman CG, Strober S, et al. $\mathrm{CD} 4+\mathrm{CD} 25+$ regulatory $\mathrm{T}$ cells preserve graft-versus-tumor activity while inhibiting graft-versus-host disease after bone marrow transplantation. Nat Med. (2003) 9:1144-50. doi: 10.1038/nm915

108. Highfill SL, Rodriguez PC, Zhou Q, Goetz CA, Koehn BH, Veenstra $\mathrm{R}$, et al. Bone marrow myeloid-derived suppressor cells (MDSCs) inhibit graft-versus-host disease (GVHD) via an arginase-1-dependent mechanism that is up-regulated by interleukin-13. Blood (2010) 116:573847. doi: 10.1182/blood-2010-06-287839

109. Leveque-El Mouttie L, Koyama M, Le Texier L, Markey KA, Cheong M, Kuns $\mathrm{RD}$, et al. Corruption of dendritic cell antigen presentation during acute GVHD leads to regulatory T-cell failure and chronic GVHD. Blood (2016) 128:794-804. doi: 10.1182/blood-2015-11-680876

110. Reddy V, Iturraspe JA, Tzolas AC, Meier-Kriesche HU, Schold J, Wingard JR. Low dendritic cell count after allogeneic hematopoietic stem cell transplantation predicts relapse, death, and acute graft-versus-host disease. Blood (2004) 103:4330-5. doi: 10.1182/blood-2003-09-3325

111. Fearnley DB, Whyte LF, Carnoutsos SA, Cook AH, Hart DN. Monitoring human blood dendritic cell numbers in normal individuals and in stem cell transplantation. Blood (1999) 93:728-736.

112. Vakkila J, Thomson AW, Hovi L, Vettenranta K, Saarinen-Pihkala UM. Circulating dendritic cell subset levels after allogeneic stem cell transplantation in children correlate with time post transplant and severity of acute graft-versus-host disease. Bone Marrow Transplant. (2005) 35:501-7. doi: 10.1038/sj.bmt.1704827

113. Malard F, Mohty M. New insight for the diagnosis of gastrointestinal acute graft-versus-host disease. Mediat Inflamm. (2014) 2014:701013. doi: 10.1155/2014/701013

114. Mohty M, Blaise D, Faucher C, Bardou VJ, Gastaut JA, Viens P, et al. Impact of plasmacytoid dendritic cells on outcome after reduced-intensity conditioning allogeneic stem cell transplantation. Leukemia (2005) 19:1-6. doi: $10.1038 /$ sj.leu. 2403558

115. Lau J, Sartor M, Bradstock KF, Vuckovic S, Munster DJ, Hart DN. Activated circulating dendritic cells after hematopoietic stem cell transplantation predict acute graft-versus-host disease. Transplantation (2007) 83:839-46. doi: 10.1097/01.tp.0000258731.38149.61

116. Wikstrom ME, Fleming P, Kuns RD, Schuster IS, Voigt V, Miller G, et al. Acute GVHD results in a severe DC defect that prevents T-cell priming and leads to fulminant cytomegalovirus disease in mice. Blood (2015) 126:150314. doi: 10.1182/blood-2015-01-622837

117. Markey KA, Koyama M, Kuns RD, Lineburg KE, Wilson YA, Olver SD, et al. Immune insufficiency during GVHD is due to defective antigen presentation within dendritic cell subsets. Blood (2012) 119:5918-30. doi: 10.1182/blood-2011-12-398164

118. Liu YJ. IPC: professional type 1 interferon-producing cells and plasmacytoid dendritic cell precursors. Annu Rev Immunol. (2005) 23:275-306. doi: 10.1146/annurev.immunol.23.021704.115633

119. Hakki M, Riddell SR, Storek J, Carter RA, Stevens-Ayers T, Sudour $\mathrm{P}$, et al. Immune reconstitution to cytomegalovirus after allogeneic hematopoietic stem cell transplantation: impact of host factors, drug therapy, and subclinical reactivation. Blood (2003) 102:3060-7. doi: 10.1182/blood-2002-11-3472

120. Boeckh M, Leisenring W, Riddell SR, Bowden RA, Huang ML, Myerson D, et al. Late cytomegalovirus disease and mortality in recipients of allogeneic hematopoietic stem cell transplants: importance of viral load and T-cell immunity. Blood (2003) 101:407-14. doi: 10.1182/blood-2002-03-0993

121. Sora F, Antinori A, Piccirillo N, De Luca A, Chiusolo P, Cingolani A, et al. Highly active antiretroviral therapy and allogeneic CD34(+) peripheral blood progenitor cells transplantation in an HIV/HCV coinfected patient with acute myeloid leukemia. Exp Hematol. (2002) 30:279-84. doi: 10.1016/S0301-472X(01)00793-7

122. Wherry EJ, Blattman JN, Ahmed R. Low CD8 T-cell proliferative potential and high viral load limit the effectiveness of therapeutic vaccination. J Virol. (2005) 79:8960-8. doi: 10.1128/JVI.79.14.8960-8968.2005

123. Jamieson BD, Ahmed R. T cell memory. Long-term persistence of virus-specific cytotoxic T cells. J Exp Med. (1989) 169:1993-2005. doi: 10.1084/jem.169.6.1993

124. Gilliet M, Boonstra A, Paturel C, Antonenko S, Xu XL, Trinchieri G, et al. The development of murine plasmacytoid dendritic cell precursors is differentially regulated by FLT3-ligand and granulocyte/macrophage colonystimulating factor. J Exp Med. (2002) 195:953-8. doi: 10.1084/jem.20020045

125. Watowich SS, Liu YJ. Mechanisms regulating dendritic cell specification and development. Immunol Rev. (2010) 238:76-92. doi: 10.1111/j.1600-065X.2010.00949.x

126. Swiecki M, Colonna M. The multifaceted biology of plasmacytoid dendritic cells. Nat Rev Immunol. (2015) 15:471-85. doi: 10.1038/nri3865

127. Murphy TL, Grajales-Reyes GE, Wu X, Tussiwand R, Briseno CG, Iwata A, et al. Transcriptional control of dendritic cell development. Annu Rev Immunol. (2016) 34:93-119. doi: 10.1146/annurev-immunol-032713-120204

128. Paul F, Amit I. Plasticity in the transcriptional and epigenetic circuits regulating dendritic cell lineage specification and function. Curr Opin Immunol. (2014) 30:1-8. doi: 10.1016/j.coi.2014.04.004

129. Mildner A, Schonheit J, Giladi A, David E, Lara-Astiaso D, Lorenzo-Vivas $\mathrm{E}$, et al. Genomic characterization of murine monocytes reveals C/EBPbeta transcription factor dependence of Ly6C(-) Cells. Immunity (2017) 46:84962 e847.

130. Paul F, Arkin Y, Giladi A, Jaitin DA, Kenigsberg E, Keren-Shaul H, et al. Transcriptional heterogeneity and lineage commitment in myeloid progenitors. Cell (2015) 163:1663-77. doi: 10.1016/j.cell.2015.11.013

131. Jaitin DA, Kenigsberg E, Keren-Shaul H, Elefant N, Paul F, Zaretsky I, et al. Massively parallel single-cell RNA-seq for marker-free decomposition of tissues into cell types. Science (2014) 343:776-9. doi: 10.1126/science.1247651

132. Tian Y, Meng L, Zhang Y. Epigenetic regulation of dendritic cell development and function. Cancer J. (2017) 23:302-7. doi: 10.1097/PPO.0000000000000280

133. Shono Y, Ueha S, Wang Y, Abe J, Kurachi M, Matsuno Y, et al. Bone marrow graft-versus-host disease: early destruction of hematopoietic niche after MHC-mismatched hematopoietic stem cell transplantation. Blood (2010) 115:5401-11. doi: 10.1182/blood-2009-11-253559

134. Anderson KL, Perkin H, Surh CD, Venturini S, Maki RA, Torbett BE. Transcription factor PU.1 is necessary for development of thymic and myeloid progenitor-derived dendritic cells. J Immunol. (2000) 164:1855-61. doi: 10.4049/jimmunol.164.4.1855

135. Anderson KL, Smith KA, Conners K, McKercher SR, Maki RA, Torbett BE. Myeloid development is selectively disrupted in PU.1 null mice. Blood (1998) 91:3702-10.

136. Paul F, Arkin Y, Giladi A, Jaitin DA, Kenigsberg E, Keren-Shaul H, et al. Transcriptional heterogeneity and lineage commitment in myeloid progenitors. Cell (2016) 164:325. doi: 10.1016/j.cell.2015.12.046

137. Salmon H, Idoyaga J, Rahman A, Leboeuf M, Remark R, Jordan S, et al. Expansion and activation of $\mathrm{CD} 103(+)$ dendritic cell progenitors at the tumor site enhances tumor responses to therapeutic PD-L1 and BRAF inhibition. Immunity (2016) 44:924-38. doi: 10.1016/j.immuni.2016.03.012

138. Price JD, Hotta-Iwamura C, Zhao Y, Beauchamp NM, Tarbell KV. DCIR2+ cDC2 DCs and Zbtb32 restore CD4+ T-cell tolerance and inhibit diabetes. Diabetes (2015) 64:3521-31. doi: 10.2337/db14-1880

139. Tamura T, Tailor P, Yamaoka K, Kong HJ, Tsujimura H, O'Shea $\mathrm{JJ}$, et al. IFN regulatory factor- 4 and -8 govern dendritic cell subset development and their functional diversity. J Immunol. (2005) 174:2573-81. doi: 10.4049/jimmunol.174.5.2573 
140. Spits H, Couwenberg F, Bakker AQ, Weijer K, Uittenbogaart CH. Id2 and Id3 inhibit development of CD34(+) stem cells into predendritic cell (preDC)2 but not into pre-DC1. Evidence for a lymphoid origin of pre-DC2. $J$ Exp Med. (2000) 192:1775-84. doi: 10.1084/jem.192.12.1775

141. Ghosh HS, Cisse B, Bunin A, Lewis KL, Reizis B. Continuous expression of the transcription factor e2-2 maintains the cell fate of mature plasmacytoid dendritic cells. Immunity (2010) 33:905-16. doi: 10.1016/j.immuni.2010.11.023

142. Cisse B, Caton ML, Lehner M, Maeda T, Scheu S, Locksley R, et al. Transcription factor E2-2 is an essential and specific regulator of plasmacytoid dendritic cell development. Cell (2008) 135:37-48. doi: 10.1016/j.cell.2008.09.016

143. Thomson AW, Ezzelarab MB. Regulatory dendritic cells: profiling, targeting, and therapeutic application. Curr Opin Organ Transplant. (2018) 23:538-45. doi: 10.1097/MOT.0000000000000565

144. MacDonald KP, Rowe V, Filippich C, Thomas R, Clouston AD, Welply $\mathrm{JK}$, et al. Donor pretreatment with progenipoietin-1 is superior to granulocyte colony-stimulating factor in preventing graft-versus-host disease after allogeneic stem cell transplantation. Blood (2003) 101:2033-42. doi: 10.1182/blood-2002-05-1529

145. Waller EK, Logan BR, Harris WA, Devine SM, Porter DL, Mineishi $\mathrm{S}$, et al. Improved survival after transplantation of more donor plasmacytoid dendritic or naive $\mathrm{T}$ cells from unrelated-donor marrow grafts: results from BMTCTN 0201. J Clin Oncol. (2014) 32:2365-72. doi: $10.1200 /$ JCO.2013.54.4577

146. Hassan M, Antonova AU, Li JM, Hosoba S, Rupji M, Kowalski J, et al. Flt3L Treatment of bone marrow donors increases graft plasmacytoid dendritic cell content and improves allogeneic transplantation outcomes. Biol Blood Marrow Transplant. (2018). doi: 10.1016/j.bbmt.2018.11.029. [Epub ahead of print].

147. Nizzoli G, Krietsch J, Weick A, Steinfelder S, Facciotti F, Gruarin $\mathrm{P}$, et al. Human $\mathrm{CD} 1 \mathrm{c}+$ dendritic cells secrete high levels of IL-12 and potently prime cytotoxic T-cell responses. Blood (2013) 122:932-42. doi: 10.1182/blood-2013-04-495424
148. Gilliet M, Cao W, Liu YJ. Plasmacytoid dendritic cells: sensing nucleic acids in viral infection and autoimmune diseases. Nat Rev Immunol. (2008) 8:594-606. doi: 10.1038/nri2358

149. Chang JT, Wherry EJ, Goldrath AW. Molecular regulation of effector and memory $T$ cell differentiation. Nat Immunol. (2014) 15:1104-15. doi: 10.1038/ni.3031

150. Giannoukakis N, Phillips B, Finegold D, Harnaha J, Trucco M. Phase I (safety) study of autologous tolerogenic dendritic cells in type 1 diabetic patients. Diabetes Care (2011) 34:2026-32. doi: 10.2337/dc1 $1-0472$

151. Lee J, Zhou YJ, Ma W, Zhang W, Aljoufi A, Luh T, et al. Lineage specification of human dendritic cells is marked by IRF8 expression in hematopoietic stem cells and multipotent progenitors. Nat Immunol. (2017) 18:877-88. doi: $10.1038 /$ ni.3789

152. Helft J, Anjos-Afonso F, van der Veen AG, Chakravarty P, Bonnet D, Reis e Sousa C. Dendritic cell lineage potential in human early hematopoietic progenitors. Cell Rep. (2017) 20:529-37. doi: 10.1016/j.celrep.2017. 06.075

153. Doulatov S, Notta F, Eppert K, Nguyen LT, Ohashi PS, Dick JE. Revised map of the human progenitor hierarchy shows the origin of macrophages and dendritic cells in early lymphoid development. Nat Immunol. (2010) 11:585-93. doi: 10.1038/ni.1889

Conflict of Interest Statement: The authors declare that the research was conducted in the absence of any commercial or financial relationships that could be construed as a potential conflict of interest.

Copyright $\odot 2019$ Yu, Tian, Wang, Mineishi and Zhang. This is an open-access article distributed under the terms of the Creative Commons Attribution License (CC $B Y)$. The use, distribution or reproduction in other forums is permitted, provided the original author(s) and the copyright owner(s) are credited and that the original publication in this journal is cited, in accordance with accepted academic practice. No use, distribution or reproduction is permitted which does not comply with these terms. 